in less than half tho time and at less than half tho cost formerly necessary. A strong caso can bo made out for the claim that the elcctric water heater is moro trustworthy than any other type. At Wimbledon there are 5,000 of the self-cleaning typo installed and thero has not been a failuro. Serious accidents due to electric water heaters aro practically unknown. During tho sovere weather last winter, only twelvo heaters were put out of action, all of which functioned immediately the ice was melted in the supply pipes.

\section{A Californian School of Education}

To havo directed one of the foremost schools of education in the United States from 1898 until 1933 , to have presided during thoso thirty-fivo years over the training of ncarly threo thousand of the graduates whom it has sent out to all parts of the United States and beyond, many of them to occupy strategic positions in the educational world as pro. fessors, research workers and school and collego executives, and to crown this lifo's work by presenting it with a now 500,000-dollar building paid for out of tho procceds, judiciously invested, of sparo-tino earnings during all those years-to fow is it given in their declining years to look back on so sutisfying an achievement. It is commomorated in a pamphlet recently issued by Stanford University in connexion with the opening of the University School of Educa. tion Building - the gift of Dean (emeritus) C'ubberley and his wife. A notoworthy feature of the School since the Great War is the importance of the summer quarter, during which most of the students aro school oxecutives or teachers, contacts between whom and the School faculty have proved highly stimulating. Tho summer is indeed regarded as the most important quarter of the university year for instruction in the field of education. The delightful summer climate of the Santa Clara Valloy is ono of the School's most valuable assets. An articlo by tho present Dean emphasizes the conception that professional study in education should havo a foundation of scholarship in the social studies and in psychology and human biology. "The school has been ono of tho most static of tho social institutions. . . University schools of education. havo responsibility for dovoloping now conceptions and techniques of education which are moro adequate for moderh society," so that the school system may dovelop in tho peoplo "the vision, the creativeness, tho initiative, the critical-mindedness, the understanding, and the disciplino which will .. give expression to tho democratic socinl ideals."

\section{Museums of Norwich}

Tre Museuns Committee of the City Council has just issued a report covering ten years' development (1929-1938) in the muscums of Norwich. It has been a period of noteworthy progress, partly on account of the value and number of gifts and bequests mado to the museums, but mainly on account of tho advances mado in museum arrangement and appeal. The exterior and amenities of the Castle Museum, with its Norman keep and magnificent Norman doorway, have been attended to following tho advice of H.M. Ofice of Works, and gieat reorganization has taken place in the collections exhibited within. It was a wiso movo to reduce the excessivo spaco formerly given to exhibits, often reduplicated, of British birds, in order to allow $\&$ more balanced representation of the animal kingdom; and the creation of dioramas of representative stretches of Norfolk scenery with the appropriate flora and fauna adds greatly to the instructiveness and attraction of tho collections. In the Art Galleries the valuablo paintings of the Cotman period aro undergoing restoration where this has been found to be desirable, and a scheme of redecoration has been followed by successful experiments in tho rearranging of the pictures themselves. In other directions the muscums show that they are keeping in pace with modern dovelopments, and none of these is moro gratifying than the success of the collaboration with the Education Authority for regular visits of school classes to the various museums.

\section{Public Health Statistics of India}

The annual report of tho Public Health Commissioner to the Government of India for 1936 , in two volumes, has recently been issued (Govern. ment of India Press, Now Delhi, 1938. Vol. 1, Rs. 2, or $3 s .6 d$; vol. 2, Rs. 1, annas 10, or 2s. $9 d$ ). The stato of the public health of the civil population in Iritish Indir is surveyed in vol. 1. The mid-year estimated population was $281,866,639$-an increase of $3 \frac{1}{2}$ millions over 1935. Tho death-rate was 23, and the birth-rate 35 , per 1,000 , and tho infantile death-rato per 1,000 live births was 162, compared with 164 for 1935 . Tho deaths from cholera numbered 160,000 , some 57,000 less than in tho previous year, and those from plague wero only 13,000 , less than half the figure for 1935 ; but the deaths from smallpox numbered 104,805 or 14,000 moro than in the previous year. Deaths recorded under 'fovers' decreased by 4 per cent, but small percentago increases wero recorded in respiratory diseases and tho diarrhœa and dysentery group. Deatlis recorded from hydrophobia numbered no fower than 2,470 . In vol. 2, the general health statistics of tho British Ammy in India and of the Indian Army are considered. 'Tho general health of the troops seems to havo been well maintained, though admissions to hospital among the British were a littlo higher than in the previous year. Tho incidence of the entoric group of fovers is tho lowest over recorded, and is particularly striking among the Indian troops. There has been no corresponding reduction among the civil populution, but rather an increase. The decrease of enteric fovers in the Army must, it would seem, bo ascribed to more general and better anti-typhoid vaccination, and to a moro caroful search for, and elimination of, carriers.

\section{Child Welfare Organization}

THE League of Nations has published the annual report on child welfare prepared by the Child Wel. faro Information Centre (London: George Allen and 